\section{ekf}

VYSOKÁ ŠKOLA BÁŇSKÁ TECHNICKÁ UNIVERZITA OSTRAVA
EKONOMICKÁ FAKULTA

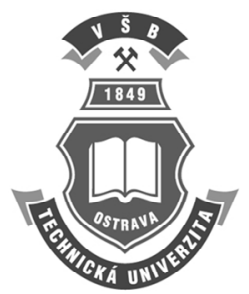

\title{
Impacts of set-aside restoration on production and incomes of Czech farmers
}

\author{
Alena KOLÁŘOVÁ*, Marie PECHROVÁ \\ Department of Economics, Faculty of Economics and Management, Czech University of Life Sciences Prague, \\ Kamýcká 129, 16521 Praha 6, Czech Republic.
}

\begin{abstract}
The creation of the Common Agricultural Policy (CAP) reflected the situation after the Second World War, when the states of the European Community were unable to ensure a sufficient level of production. However, the mechanism of the CAP caused extreme overproduction. One of the regulatory measures was the set-aside of a stated percentage of agricultural land. This was accompanied by subsidies to compensate for the loss of the production. This measure - originally voluntary, but later obligatory - was cancelled during the Health Check of the CAP in 2008. Currently there is discussion of its restoration. The article analyses how set-aside and the distribution of subsidies are reflected in the economic situation of agricultural subjects in the Czech Republic. It focuses on the effects of reducing the area of agricultural land with the obligatory setting aside of $7 \%$ of such land. The opportunity costs (revenue which farmers would gain if they were able to farm the set-aside land and sell the products on the market) were compared with the benefits in the form of subsidies. The worst impact was proved to be on the largest farms. However, lost profit from their non-realized production is compensated by subsidies to these farms, too.
\end{abstract}

\section{Keywords}

Common Agricultural Policy (CAP) post 2013, farmers income, profitability of agriculture, set-aside, subvention.

JEL Classification: Q12, Q14, Q18

\footnotetext{
* alka.kolarova@gmail.com (corresponding author)
}

The paper was supported by the internal grant Využití finančních prostředků fondi̊ EU pro rozvoj venkova No. 20121054:11110/1312/3112 of the Internal Grant Agency of the Faculty of Economics and Management of the Czech University of Life Sciences in Prague. 


\title{
Dopady znovuzavedení půdy do klidu na produkci a př́ijmy zemědělců v ČR
}

\author{
Alena KOLÁŘOVÁ, Marie PECHROVÁ
}

\section{1. Úvod}

Od vzniku Společné zemědělské politiky (SZP) patřila otázka př́ijmů zemědělských výrobců k hlavním, které byly $\mathrm{v}$ rámci této politiky řešeny a ovlivňovaly její orientaci a obsah. Di̊vodem je skutečnost, že pokud by provozování zemědělských aktivit nepřinášelo zemédělcưm žádoucí finanční efekt, logicky by docházelo kukončení podnikatelské činnosti $v$ zemědělství, $k$ zániku hospodářství, $k$ nežádoucímu odlivu obyvatelstva venkova za jiným způsobem obživy a výsledně by se tyto jevy negativně promitly do v̌̌ech funkcí, které dnes zemédělství naplňuje (Boháčková, 2001). Mezi původní cíle SZP patřilo: zvýšit produktivitu zemědělské výroby, zajistit přiměřenou životní úroveň zemědělcům, stabilizovat trhy a zajistit plynulé zásobování a dodávky spotřebitelům za rozumné ceny. $\mathrm{K}$ dosažení vytyčených záměrů bylo využito nástrojů přímo podporujících produkci, nejvíce tržních intervencí. Rostoucí produktivnost evropského zemědělství spolu s konstantní poptávkou vedla k relativně rychlému dosažení soběstačnosti až nadprodukci. Rozpočtové výdaje směřující na SZP se zvyšovaly a stávaly se neudržitelnými. $V$ di̊sledku situace na trhu EU a vnéjšich sil byla SZP za poslednich 25 let systematicky reformována (Majewski a Sulewski, 2010). Jedním z opatření pro snížení nadvýroby bylo uvádění půdy do klidu (set-aside). Opatření zavedené v roce 1988 bylo původně pro členské země EU15 dobrovolné. Reformou SZP v roce 1992 se však stalo povinným (Morris a kol., 2011). Ačkoli se dle hodnocení ex-post prokázal pozitivní vliv na snížení přebytků, set-aside je závažným zásahem do svobodného rozhodování zemědělského subjektu o výši a struktuře produkce s dopady do výše jeho př́jmů a s celou řadou dalších efektů, které musí být podrobně analyzovány. V kontextu reformy SZP po roce 2013 je navrhováno opatření vynětí půdy $\mathrm{z}$ produkce opět zavést. Vede se veřejná debata o pozitivních a negativních účincích tohoto systému. Dopady znovuzavedení opatření mohou být posuzovány $\mathrm{z}$ různých úhlů pohledu. $\mathrm{Z}$ ekologického hlediska se hodnotí prrínos půdy ponechané ladem pro zvýšení biodiverzity. Ve vztahu ke změně nabídky farmářů jako reakce na omezení nakládání s půdou např́klad Ball a kol. (1997) zkoumají, jak se změní po ponechání části půdy ladem skladba pěstovaných plodin, jestliže zemědělci alokují půdu na základě principu maximalizace zisku. Rygnestad a Fraser (1996) modelují snížení zemědělského výstupu jako celku. Finanční dopady opatření set-aside zkoumá například Koester (1989). Ty se mohou projevit nejen v prŕijmech zemědělců, ale i výdajích na SZP. Předmětem výzkumu je i zlepšování podmínek set-aside. Fraser (2001) navrhuje, aby existovala diferenciovaná výnosová základna založená na kvalitě půdy, která by předešla nepř́znivému výběru méně kvalitní půdy pro ponechání ladem. Zároveň doporučuje zahrnout do sledovaných kritérií půdy ponechané ladem nejen kvantitativní, ale i kvalitativní hlediska.

Cílem článku je analyzovat dopady znovuzavedení opatření set-aside v ČR do výše produkce vyjádřené naturálně a hodnotově. Nejprve je nastíněn př́istup jednotlivých autorů k problematice. Následuje popis metodických postupů, prostřednictvím kterých je naplněn cíl článku. Jednotlivé analýzy jsou uvedeny a diskutovány ve třetí části. Jsou rozebrány dopady na národní i podnikové úrovni. Zkoumají se vlivy na př́ijmy zemědělců, výměru obdělávané půdy a na produkci. Rovněž je zvažována situace, kdy zemědělec hospodaří na pronajaté půdě. Závěrečná část sumarizuje výsledky provedených analýz.

\section{Dosavadní reformy Společné zemědělské politiky}

Cílem řady reforem bylo snížit náročnost SZP na financování. V roce 1988 se kličovým prvkem stabilizačních programů stal systém uvádění půdy do klidu (Novák a kol., 2006). Představoval prrímou reakci na nadprodukci obilovin a fungoval na dobrovolné bázi. Zemédělci, kteři uzavřeli smlouvu, dostávali plnou náhradu za nerealizované přijmy. Zpočátku uváděli do klidu méně úrodnou půdu a získané prostředky využili $k$ intenzifikaci výroby na úrodnější části pozemků (Novák a kol., 2006). To si vyžádalo zpřesňování podmínek, k čemu lze půdu v klidu využít. Systém uvádění půdy do klidu se stal povinným až v r. 1992 MacSharryho reformou SZP a opatřeni od té doby prošlo řadou změn. Ačkoli bylo zavedeno za účelem omezeni výroby, brzy bylo žrejmé, že znovuzavedení půdy ponechané v klidu do osevního postupu na orné půdě má potenciál prispět ke zvýšení biodiverzity, ochraně zdrojů a poskytnout další přinosy pro životní prostředí (DEFRA, 2011). Studie Corbetové (1995) 
dokazuje, že půda dlouhodobě ponechaná v klidu (10leté období regenerace po orbě), má prríznivé účinky na zachování živočišných druhů žijících v dlouhodobé vegetaci. Povinné ponechání pưdy v klidu v rámci SZP príneslo široká pozitiva pro divoké polní živočišné druhy (Herzon a kol., 2011). Ve svém výzkumu Herzon a kol. (2011) dokazují, že přítomnost půdy ponechané $\mathrm{v}$ klidu na pozemcích farmy má př́iznivý účinek na zvýšený výskyt různých druhů ptactva.

Předpokládá se, že i když na půdě nebude nic pěstováno, zemědělci ji budou udržovat. Nařízení Rady (EHS) č. 2078/92 z 30. července 1992 o zemědělských výrobních metodách kompatibilních s požadavky na ochranu životního prostředí a údržbu krajiny (Evropská komise, 1992) mělo v úmyslu podporovat dlouhodobé ponechání zemědělské půdy $\mathrm{v}$ klidu $\mathrm{z}$ důvodů spojených se životním prostředím. Záměry ponechání půdy ladem byly spíše naznačeny než explicitně vyjádřeny. Výzkum Clémenta a kol. (2002) identifikoval následující specifické cíle: příspěvek půdy $\mathrm{v}$ klidu $\mathrm{k}$ rovnováze na trhu snížením přebytků produkce, rozvoj pěstování nepotravinářských plodin, zachování kvality životního prostředí, pomoc malým farmářům.

Půdu museli povinně uvádět do klidu pěstitelé, kteři byli předmètem všeobecné úpravy a jejichž půda predstavovala v prüměru $72 \%$ výméry plodin na orné půdě Evropských společenství (Clément a kol., 2002). $\mathrm{Na}$ malé farmáře, jejichž produkce nedosahovala úrovně 92 t obilovin za rok, se set-aside nevztahovalo. Opatřeni vyžadovalo od zemédělcủ, aby vyňali část orné půdy z produkce $v$ míre stanovované každoročně Radou. Ačkoli to nebylo vyjádřeno explicitnè, cílem opatřeni bylo sniženi produkce obilnin, které byly v prebytku, a sniženi úrovně zásob, které se staly počátkem devadesátých let citlivým tématem (Clément a kol., 2002). Závazek ponechání určitého procenta půdy podniku ladem (tj. bez produkce) bylo možno splnit i prostřednictvím pěstováni nepotravinářských plodin na půdě vyñaté z produkce podle režimu nepotravinářské produkce na pưdě vyn̆até z produkce (NFSA) (Vannini a kol., 2008). Podíl půdy uvedené do klidu byl původně stanoven na $15 \%$ a v roce 1996 snížen na $10 \%$. Novinkou bylo zavedení nepovinného systému půdy v klidu výměnou za platbu a zavedení možnosti stálého ponechání půdy $\mathrm{v}$ klidu jako protikladu ke střídavému systému, které bylo původně jedinou formou opatření. Nicméně podle hodnocení ex-post nemělo nepovinné uvádění půdy do klidu takový efekt jako povinné. Podle konzultací s dotčenými farmáŕi by zhruba třetina až polovina půdy v uvedeném období stejně byla do klidu dobrovolně uvedena (Clément a kol., 2002). V uvedených letech se rozšířilo pěstování plodin pro nepotravinářské užití, především v zemích, kde byla tato produkce daňově zvýhodněna a existovala infrastruktura pro zpracování těchto plodin.

Reforma Agenda 2000 pouze stanovila povinnou sazbu vynětí půdy $\mathrm{z}$ produkce na $10 \%$. Komise v rámci př́pravy reformy SZP v roce 2003 navrhla nahradit stávající režim nepotravinářské produkce na půdě vyňaté $\mathrm{z}$ produkce uhlikovým kreditem, tedy finanční podporou pro energetické plodiny nezávislou na konkrétní plodině, jejímž cílem je nahradit oxid uhličitý. Režim pěstování na půdě vyňaté z produkce by se přitom změnil na povinný dlouhodobý nestřídavý režim pěstování. Ve výsledku však zůstalo setaside zachováno a nově byly zavedeny podpory pro produkci energetických plodin. Režim NFSA a podpora energetických plodin fungovaly současně. Byla potvrzena úloha půdy vyñaté z produkce jako nástroje pro kontrolu nabidky, navic byl výslovně uznán pozitivni dopad tohoto opatřeni na životni prostředí (Vannini a kol., 2008). Zatímco do reformy se týkalo pouze obilovin, olejnatých semen a bílkovinných plodin, po roce 2003 se vyčlenění produkce vztahovalo na všechny plodiny na orné půdě. Jako odpověd' na vysoké ceny zemědělských komodit v letech 20072008, obavy vztahující se $\mathrm{k}$ bezpečnosti potravin a tlak zemědělského průmyslu na odstranění restrikcí na využití půdy, stanovila EU plochu půdy uvedené do klidu na $0 \%$ a poté ji zcela zrušila během tzv. Health Check SZP v roce 2008 (Morris a kol., 2011).

Návrh Evropské komise pro víceletý finanční rámec 2014-2020 požaduje, aby v rámci budoucí SZP museli farmáŕi vyhovět třem povinným požadavkům při využívání své půdy (zasít aspoň 3 plodiny, neosévat $7 \%$ půdy a zachovávat trvalé travní porosty). Zatímco $\mathrm{v}$ předchozích reformách šlo o snižování přebytků produkce, $v$ nynějším návrhu je opatření setaside zahrnuto $v$ kapitole plateb na zemědělské postupy př́iznivé pro klima a životní prostředí. Opatření, která počítají s vyčleněním $7 \%$ zemědělské půdy z produkce (na této půdě by mohla růst naprííklad tráva, stromy) nebo střídáním plodin, mají mít podle Komise (Evropská komise, 2011) dvojí účinek zvýšit produktivitu a posílit odolnost vưči vlivům změn klimatu. Farmáŕi mají povinnost se o půdu vyňatou $\mathrm{z}$ produkce starat. Zemédělci zajistí, aby nejméně $7 \%$ hektarů, na něž lze poskytnout podporu, $s$ výjimkou ploch porostlých trvalými travními porosty, bylo plochou využivanou v ekologickém zájmu, jako jsou např. pozemky ležici ladem, terasy, krajinné znaky, ochranné pásy a zalesnèné oblasti. Komise může presněji definovat druhy ploch využivaných $v$ ekologickém zájmu a doplnit a definovat dalši druhy ploch využivaných v ekologickém zájmu, které lze vzit v úvahu při dodržování procentního podílu (Evropská komise, 2011). Specifikace konkrétních účelů, ke kterým lze půdu ponechanou v klidu využít, je klíčová pro další úvahy o set-aside. Podle Clémenta a kol. 
(2002) by měla být definice typu kultury pěstované na pưdě vyňaté z produkce, délka trvání, velikost parcel apod. plně v kompetenci členských států. Umožnilo by to větši flexibilitu, která je vzhledem $\mathrm{k}$ diferencím mezi agrárními sektory členských států potřebná.

\section{Data a metodika}

Cílem článku je analyzovat, jaký dopad by mělo povinné uvedení $7 \%$ půdy do klidu na snížení výměry zemědělské půdy. Byly zkoumány typové situace pro jednotlivé velikostní třídy zemědělských podniků. Modelový př́stup ve své analýze zohledňuje i dopady na podniky $\mathrm{z}$ hlediska vlastnictví fyzickými nebo právnickými osobami. Pro simulaci účinků ponechání půdy ladem jsou využity roky, kdy opatření v ČR nefungovalo, tj. 2009 a 2010. Analýza vychází z cenzového šetření Českého statistického úřadu Agrocenzus 2011 a $\mathrm{z}$ výběrového šetření zemědělských podniků $\mathrm{v}$ rámci Farm Accountancy Data Network (FADN, 2010) za rok 2009. Reprezentativní vzorek podniků uvedený $\mathrm{v}$ tabulce 1 postačuje pro zpracování a vysvětlení základních rozdílů v dopadech na zemědělské podniky.

Tabulka 1 Typologie a výběrový soubor podniků

\begin{tabular}{|l|c|c|c|c|}
\hline $\begin{array}{l}\text { Ekonomická } \\
\text { velikost }\end{array}$ & $\begin{array}{c}\text { Malá } \\
(I I I .-V I .)\end{array}$ & $\begin{array}{c}\text { Středni } \\
\text { VII.-VIII. })\end{array}$ & $\begin{array}{c}\text { Velká } \\
(I X .)\end{array}$ & $\begin{array}{c}\text { Největši } \\
(X .)\end{array}$ \\
\hline $\begin{array}{l}\text { Počet podniků } \\
\text { v souboru }\end{array}$ & 232 & 529 & 179 & 421 \\
\hline $\begin{array}{l}\text { Reprezentované } \\
\text { podniky }\end{array}$ & 6963 & 4879 & 994 & 1417 \\
\hline $\begin{array}{l}\text { Ekonomická } \\
\text { velikost [EVJ] }\end{array}$ & 10,0 & 39,0 & 161,9 & 701,8 \\
\hline
\end{tabular}

Zdroj: FADN (2010)

a EVJ...1 200 EUR standardizovaného ekonomického př́nosu rostlinné a živočišné výroby.

Typologie zemědělských podniků odpovídá metodice EU, která zařazuje podniky podle jejich ekonomické velikosti do 10 velikostních trríd dle standardního př́spěvku na úhradu. Ten vyjadřuje ekonomický prínos jednotky produkce jednotlivých odvětví rostlinné a živočišné výroby. Jeho hodnota odpovidá standardni hodnoté produkce z 1 ha dané plodiny po odpočtu variabilních nákladi na produkci této výroby (FADN, 2011). Metodika vychází z analýzy hospodáŕských výsledků zemědělských podniků oficiálně publikovaných za jednotlivé typy podniků $\mathrm{v}$ rámci systému FADN (do výsledků je zahrnuta pouze zemědělská činnost, nikoliv přidružená výroba).

Modelová analýza komparuje ušlé výnosy produkce s prrímými platbami, na které má podnik při dodržení podmínek nárok. Režim ponechání půdy ladem nevyžaduje stejné náklady jako pěstování plodin, je nutné brát $\mathrm{v}$ úvahu náklady ušlé prríležitosti, respektive zisk, který by farmáři mohli získat, pokud by na půdě dané do klidu plodiny pěstovali a následně je realizovali na trhu. $Z$ výchozích agregovaných dat jsou provedeny analýzy skutečných účetních výkazů zemědělských podniků a modelovány teoretické situace, které by nastaly prŕpadným uvedením půdy do klidu. Těžištěm problematiky je komparace nákladů ušlé př́ležitosti, respektive zisku (který farmáři uvedením půdy do klidu nerealizují) s celkovými př́mými platbami, které si podnik při dodržení podmínek při zavádění půdy do klidu může nárokovat. V závislosti na konkrétních potřebách hodnocení efektů ve vztahu $\mathrm{k}$ nákladům či př́jmům zemědělských podniků jsou základním metodickým nástrojem v rámci aplikovaných horizontálních a vertikálních analýz absolutní, rozdílové a poměrové ukazatele.

\section{Diskuse}

Vzhledem ke specifické situaci co do velikosti a struktury zemědělských podniků v České republice jsou nejprve analyzovány dopady zavedení opatření na národní úrovni. Poté jsou detailně rozebrány vlivy na př́ijmovou situaci zemědělců, výměru obdělávané půdy a produkci dle velikostní kategorie podniku. $\mathrm{Na}$ závěr je zvažována situace, kdy zemědělec hospodaří na pronajaté půdě.

\subsection{Dopady zavedení půdy do klidu na zeměděl- ství ČR jako celek}

Celková výměra orné půdy v ČR pro rok 2010 byla 3483 mil. ha. Při hodnocení dopadů systému set-aside musí být brána $\mathrm{v}$ úvahu specifika zemědělství regionu, tj. struktura $\mathrm{z}$ hlediska ekonomické velikosti farem, poměru fyzických (FO) a právnických osob (PO), podíl pronajaté půdy atd. V ČR převažují $F O$, které představují téměř $87 \%$ všech zemědělských subjektů. Obhospodařují však pouze $29 \%$ půdy. PO je sice výrazně méně, hospodaří však na téměř $71 \%$ půdy. Průměrně na jeden podnik FO připadá 51,22 ha a na PO 801,23 ha (ČSÚ, 2010). Požadavek na 7\% uvedení půdy do klidu by tedy $\mathrm{v}$ průměru odebral průměrnému podniku FO 3,59 ha a velkému 56,09 ha. Celkem by muselo být uvedeno do klidu 243845 ha z celkové obhospodařované zemědělské půdy za předpokladu, že by na ni chtěli zemědělci dostávat dotace. Půda ponechaná ladem existuje i z důvodů nezávislých na stanovené povinnosti. Podle šetření Agrocenzus (ČSÚ, 2010) bylo v ČR ponecháno ladem celkem 37460 ha půdy (tj. 1,49 \% z celkově obhospodařované půdy), z čehož na téměř $75 \%$ výměry byly poskytovány dotace. Zatímco FO pobíraly dotaci na 7165 ha, PO na téměř $3 x$ vyšší výměru. Avšak zatímco $F O$ již nyní ponechaly $1,63 \%$ své půdy ladem, PO pouze $1,44 \%$. $\mathrm{Z}$ tohoto hlediska by pro FO mělo být přijatelnější podíl půdy ponechané ladem navýšit. Situaci ilustruje tabulka 2. 
Tabulka 2 Orná půda ponechaná ladem (v ha) k 30. 9. 2010

\begin{tabular}{|l|c|c|c|}
\hline $\begin{array}{l}\text { Orná půda } \\
\text { ladem }\end{array}$ & Fyzické osoby & $\begin{array}{c}\text { Právnické } \\
\text { osoby }\end{array}$ & Celkem \\
\hline bez dotací & 2943,92 & 6563,52 & 9507,44 \\
\hline s dotacemi & 7165,38 & 20786,87 & 27952,25 \\
\hline Celkem & 10109,30 & 27350,39 & 37459,69 \\
\hline
\end{tabular}

\subsection{Dopady zavedení půdy do klidu na př́ijmy zemědělců v ČR}

$\mathrm{V}$ modelové situaci porovnáme výši kompenzace (v podobě př́mé platby na plochu ve výši 4 060,80 $\mathrm{Kč} / \mathrm{ha}$ ) s vybranými plodinami s největším podílem na orné půdě. $V$ roce 2010 byla průměrná realizační cena pšenice $3392 \mathrm{Kč/t}$, tj. (př̀i výnosu 5,08 t/ha) 17231 Kč/ha. Je zřejmé, že SAPS není dostatečnou kompenzací ušlých př́ijmů. Jestliže zemědělec vyčlení $7 \%$ z osevní plochy, kde dř́ve pěstoval řepku, při průměrné farmářské ceně $7737 \mathrm{Kč} / \mathrm{t}$ a výnosu 2,83 t/ha přijde o $21896 \mathrm{Kč} / \mathrm{ha}$. Přehled ušlých výnosů u dalších plodin zobrazuje tabulka 3.

Dále budou zemědělci porovnávat výši všech dotací, které dostanou na všechny oprávněné hektary, $\mathrm{s}$ výnosy, o které přijdou uvedením půdy do klidu. Každý zemědělec si spočítá, kterou plochu vyřadí z produkce tak, aby utrpěl co nejmenší ztráty. Je pochopitelné, že zemědělci budou tíhnout $\mathrm{k}$ tomu, aby pro půdu uvedenou do klidu vyčlenili ty části svého hospodářství, které jsou nejméně produktivní (půda chudá na živiny, okrajové části, mokřady atd.) nebo se velmi špatně kultivují, jako např. vzdálené či malé pozemky.

\subsection{Dopady zavedení půdy do klidu podle veli- kostních kategorií}

U podniků spadajících do kategorie malá odpovídá $7 \%$ výměry orné půdy dané do klidu jedním podnikem 2,38 ha. $\mathrm{V}$ důsledku opatření poklesne úroveň agrární produkce a podnik obětuje výnos $\mathrm{v}$ hodnotě 29916 Kč. Celková suma vyplacených dotací na úhrn zemědělské půdy na podnik by činila 266760 Kč. Zemědělský podnik tak na jeden hektar získá dotaci ve výši 7777 Kč. Alternativní výnos, který zemědělec získá zavedením opatření, téměř 9krát pokryje ušlý výnos jeho původní činnosti. Tabulka 4 vyčísluje vlivy na produkci podniků vzniklé uvedením $7 \%$ půdy do klidu.

Agrární produkce podniků $\mathrm{v}$ dalších kategoriích a i následná změna produkce, která nastává uvedením půdy do klidu, se mění v závislosti na rozsahu výroby a výkonnosti jednotlivých podniků, kde dochází, vlivem určité diferenciace ve vývoji jednotlivých nákladových položek, ke změnám ve finální produkci. Mezi zemědělci malé, střední i velké kategorie lze shledat proporcionalitu. Neúměrné a markantní rozdíly jsou však zachytitelné u podniků z kategorie malé a největší, proto jsou dále podrobněji analyzovány a srovnávány náklady a efekty zemědělských producentů $\mathrm{z}$ těchto kategorií.

Změna produkce uvedením půdy do klidu u ejvětších producentů představuje pokles výroby o 1,727 mil. Kč na podnik. Př́ijem z dotací uhradí tyto ušlé výnosy pouze 6krát, u malých podniků 9 krát. Příčiny lze odvozovat $\mathrm{z}$ úrovně nákladů, kde lze u velkých podniků předpokládat levnější výrobu dosahující úspor $\mathrm{z}$ rozsahu. Změna produkce ztrátou $7 \%$ orné půdy vede $\mathrm{k}$ velké ztrátě na výnosech. Při bližší analýze nákladů vstupuje u podniků této kategorie do výrobní spotřeby, která tvoří největší podíl celkových nákladů, sice méně osiv (nakupovaných i vlastních), ale i velkou měrou nákup hnojiv a prostředků na ochranu rostlin. Intenzifikace sice zvyšuje náklady, ale u největších podniků koresponduje s větším výnosem na hektar než u podniků malých. U pšenice se jedná o rozdíl téměř $0,8 \mathrm{t} / \mathrm{ha}$ a u kukuřice o $1,5 \mathrm{t} / \mathrm{ha}$. Značnou část této výhody a tím i realizaci zisku však uváděním půdy do klidu ztrácejí.

\subsection{Půda v klidu ve vztahu $k$ nákladům podniku}

Specifikem českého zemědělství je vysoký podíl pronajaté půdy. PO hospodaří až na $87,4 \%$ pronajaté půdy, FO na 55,01\%. Existuje pravděpodobnost, že by část půdy $\mathrm{v}$ klidu byla zároveň půdou pronajatou. Došlo by tak k paradoxu, kdy zemědělec musí platit za půdu, kterou nejen že nevlastní, ale ani nevyužívá. Vyvstává tedy otázka, do jaké míry je pro zemědělský podnik únosné hradit pachtovné za půdu, kterou obětoval př́ležitosti čerpání finančních prostředkủ z EU, a jakým způsobem se dotace podílí na úhradě nájemného.

Malé podniky vykonávají svoji činnost ze $47 \%$ na vlastních pozemcích na rozdíl od podniků největšich, které hospodaří na orné půdě z $93 \%$ připachtované. Právnických osob (kategorie největši je tvořena převážně jimi) se dotklo výrazné zdražování pachtovného, meziroční nárůst $\mathrm{v}$ roce 2009 u PO byl 9,4 \% (FADN, 2010). Společně s nájemným se výraznou měrou do sumy externích nákladů promítají i mzdové náklady (náklady na mzdy a sociální pojištění placených sil), u největších podniků o $1232 \%$ vyšší než u podniků malých, tj. $708 \mathrm{Kč} /$ ha malé podniky a 8727 Kč/ha největší. Objemnou nákladovou položkou ve srovnání s malými podniky je i krytí majetku cizím kapitálem a úvěrové zatížení. Největší podniky stálá aktiva pokrývají z jedné čtvrtiny cizími dlouhodobými zdroji, kdežto malé podniky dlouhodobý majetek hradí cizím dlouhodobým kapitálem pouze z $8 \%$. Tyto položky představují fixní náklady, které při klesajícím objemu agrárních výkonů ( $v$ důsledku vynětí půdy $\mathrm{z}$ produkce) na jednotku rostou. Relativní úspora fixních nákladů klesá, což je neprríznivé z hlediska 
př́spěvku na úhradu a následné tvorby konečného důchodu ze zemědělské činnosti. U sledovaných podniků z kate-gorie malé po modifikaci výpočtů činí pachtovné za půdu v klidu (1,24 ha/podnik) 773 Kč. Výše vyčíslená suma dotací 266760 pokrývá náklady na pronájem půdy 345 krát. Porovnání výše dotací a pachtovného pro všechny velikostní kategorie podniků je uvedeno $v$ tabulce 5 .

Př́ijmy $\mathrm{z}$ dotací jsou $\mathrm{v}$ případě malých podniků schopny uhradit pachtovné a náklady ušlé př́ležitosti (NUP) 8,7krát. V kategorii středních podniků přijaté finanční prostředky pokryjí náklady vzniklé v souvislosti se změnou produkce a pachtovným celkem 5 krát.

Tabulka 3 Změna tržeb zemědělců při snížení výměry vybraných plodin o 7 \%

\begin{tabular}{|c|c|c|c|c|c|c|c|}
\hline & $\begin{array}{c}\text { Pšenice } \\
\text { ozimá }\end{array}$ & $\begin{array}{c}\text { Repka } \\
\text { semeno }\end{array}$ & Ječmen jarní & $\begin{array}{l}\text { Kukuřice na } \\
\text { zeleno a siláž }\end{array}$ & $\begin{array}{c}\text { Kukuřice na } \\
\text { zrno }\end{array}$ & Mák setý & $\begin{array}{l}\text { Brambory } \\
\text { rané }\end{array}$ \\
\hline (\%) z orné půdy & 30,92 & 14,52 & 10,97 & 7,03 & 4,07 & 2,01 & 0,05 \\
\hline Výnos $(t / h a)$ & 5,08 & 2,83 & 3,91 & 33,04 & 6,71 & 0,46 & 19,01 \\
\hline Cena $(K \check{c} / t)$ & 3392 & 7737 & 3408 & 3282 & 2500 & 24725 & 6304 \\
\hline $\begin{array}{l}\text { Ztráta tržeb } \\
(K \check{c} / h a)\end{array}$ & 17231,36 & 21895,71 & 13325,28 & 108437,28 & 16775,00 & 11373,50 & 119839,04 \\
\hline
\end{tabular}

Zdroj: FADN (2010), vlastní výpočty

Tabulka 4 Vliv set-aside na výměru a produkci podle ekonomické velikosti podniků

\begin{tabular}{|c|c|c|c|c|c|}
\hline Ekonomická velikost podniku & $\begin{array}{c}\mathrm{EVJ} / \\
\text { podnik }\end{array}$ & $\begin{array}{c}\text { Malá } \\
\text { (III.-VI.) }\end{array}$ & $\begin{array}{c}\text { Střední } \\
\text { (VII.-VIII.) }\end{array}$ & $\begin{array}{l}\text { Velká } \\
(I X .)\end{array}$ & $\begin{array}{l}\text { Nejuétší } \\
(X .)\end{array}$ \\
\hline Původní výměra 1 podniku & ha & 34,30 & 122,10 & 461,30 & 1477,00 \\
\hline Změna výměry (7%) & ha & $-2,38$ & $-8,54$ & $-32,09$ & $-103,16$ \\
\hline Původní produkce $R V$ & 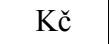 & 427375 & 1492811 & 5658950 & 24678662 \\
\hline Změna produkce (=výnosů) & Kč & $-29916,28$ & $-104496,75$ & $-396126,50$ & $-1727506,30$ \\
\hline Di̊chod ze zemédělské činnosti ${ }^{\mathrm{b}}$ & $\mathrm{Kč} / \mathrm{ha}$ & 174133,33 & 536690,69 & 924569,35 & $-945939,53$ \\
\hline Podil změny produkce na důchodu ze zemédèlské činnosti & & $-17,18 \%$ & $-19,47 \%$ & $-42,84 \%$ & $182,62 \%$ \\
\hline Dotace na všechny ha ${ }^{\mathrm{c}}$ & Kč & 266759,68 & 562557,11 & 2006576,64 & 10428678,30 \\
\hline Poměr dotací $k$ výnosům z půdy v klidu & - & 8,92 & 5,38 & 5,07 & 6,04 \\
\hline
\end{tabular}

Zdroj: FADN (2010), vlastní výpočty

Pozn: EVJ je Evropská velikostní jednotka, RV je rostlinná výroba.

${ }^{\mathrm{b}}$ Čistá přidaná hodnota po zohlednění salda investičních daní a dotací a odečtení nákladů na externí faktory.

${ }^{c}$ Dotace na ha zemědělské půdy 7 777,25 (SAPS a Top-up) násobené celkovou výměrou podniku.

Tabulka 5 Porovnání celkové výše dotací a pachtovného

\begin{tabular}{|l|c|c|c|c|c|}
\hline Ekonomická velikost podniku & $\begin{array}{c}\text { EVJ/ } \\
\text { podnik }\end{array}$ & $\begin{array}{c}\text { Malá } \\
(I I I .-V I .)\end{array}$ & $\begin{array}{c}\text { Střední } \\
(\text { VII.-VIII.) }\end{array}$ & $\begin{array}{c}\text { Velká } \\
\text { (IX.) }\end{array}$ & Největši (X.) \\
\hline Půda do klidu celkem & ha & 2,38 & 8,54 & 32,09 & 103,16 \\
\hline z toho připachtovanád $^{\text {d }}$ & ha & 1,24 & 6,16 & 26,48 & 96,86 \\
\hline Pachtovné & Kč/ha & 623,03 & 950,42 & 4503,35 & 8726,65 \\
\hline Pachtovné za pudu v klidu & Kč & 773,18 & 5851,55 & 119255,96 & 845291,96 \\
\hline SAPS & Kč/ha & 3682,45 & 3698,89 & 3693,16 & 3695,93 \\
\hline Top-up & Kč/ha & 4094,80 & 4607,35 & 4349,83 & 3364,68 \\
\hline Dotace celkem & Kč/ha & 7777,25 & 8306,24 & 8042,99 & 7060,61 \\
\hline Dotace na plochu celkem & Kč & 266759,68 & 562557,11 & 2006576,64 & 10428678,25 \\
\hline Krytí pachtovného dotacemi & - & 345,02 & 96,14 & 16,83 & 12,34 \\
\hline
\end{tabular}

Zdroj: FADN (2010), vlastní výpočty

Pozn.: EVJ je Evropská velikostní jednotka, SAPS je Single Area Payment Scheme - jednotná platba na ha zemědělské půdy, Top-up jsou národní doplňkové platby - jsou poskytovány navíc k SAPS a slouží k navýšení plateb u vybraných komodit.

${ }^{\mathrm{d}}$ Procentický podíl připachtované zemědělské půdy v klidu je odvozen z celkového podílu připachtované půdy využivané jednotlivými skupinami podniků: malé podniky $52,1 \%$, střední $72,1 \%$, velké $82,5 \%$, největší podniky $93,9 \%$ zemědělské půdy. 
Podniky $\mathrm{v}$ kategorii velké stejně jako podniky $\mathrm{v}$ kategorii největši tyto náklady uhradí z dotací téměr 4krát. Celkovou bilanci dotací po uhrazení ušlých výnosů a pachtovného zachycuje níže uvedená tabulka 6.

\section{Závěr}

Článek modeluje situaci v zemědělství ČR, která by vznikla zavedením opatření set-aside jako jedné z podmínek pro získání prímých plateb. Komparuje náklady ušlé př́ležitosti (zisk, který by farmáŕi získali, pokud by na půdě v klidu plodiny pěstovali a realizovali je na trhu) s prínosy v podobě získaných dotací. Zavedení opatření by na ekonomickou situaci podniku mělo negativní vliv $\mathrm{v}$ př́padě, že by dotační platba byla vztažena pouze na úhrn půdy dané do klidu. Ve skutečnosti se platby z dotačních titulů vztahují na celkovou výměru zemědělského hospodářství.

Při srovnání celkové výše dotace $\mathrm{s}$ náklady ušlé př́ležitosti docházíme k závěru, že se dopady set-aside liší dle ekonomické velikosti podniku. Nejméně př́znivé jsou výsledky pro podniky v kategorii největší, u nichž ztráta produkce snižuje relativní úsporu fixních nákladů (klesají rostoucí výnosy z rozsahu) a zvyšuje náklady více než u malých podniků. Nicméně dotační prostředky SZP nejenže kompenzují, dokonce několikanásobně překračují ušlý zisk způsobený snížením výměry orné půdy o $7 \%$. Zemědělskému podniku se vyplatí obětovat produkci. Neobstojí ani argument vysokého procenta pronajaté půdy v ČR. U malých podniků pokrývají dotace pachtovné a náklady ušlé př́ležitosti téměř 9 krát, u středních 5 krát, velkých a největších 4 krát. Rozdíly jsou dány diferencemi $\mathrm{v}$ nákladových funkcích podniků různé ekonomické velikosti. Farmáři sice budou platit pachtovné za půdu, kterou nevyužívají (na PO bude dopad markantnější, protože využívají více připachtované půdy), nicméně i přesto je výše dotace silným motivačním faktorem pro dodržení pravidel a ponechání půdy v klidu.

\section{Literatura}

BALL, V. E. a kol. (1997). CAP reform: Modelling supply response subject to the land set-aside. Agricultural Economics 17(2-3): 277-288.

http://dx.doi.org/10.1016/S0169-5150(97)00026-1

BOHÁČKOVÁ, I. (2011). Účinnost podpor v oblasti př́jmů zemědělských producentů. In: Boháčková, I. a kol.: Finanční podpora zemédělství a regionálního rozvoje - vybrané aspekty. Praha, Powerprint Praha, 57-75.

CORBET, S. (1995). Agriculture, ecosystems: Insects, plants and succession: advantages of long-term setaside. Agriculture, Ecosystems and Environment 53(3): 201-217. http://dx.doi.org/10.1016/0167$\underline{8809(94) 00581-X}$

FRASER, R. (2001). Using principal-agent theory to deal with output slippage in the European Union setaside policy. Journal of Agricultural Economics 52(2): $29-41$.

http://dx.doi.org/10.1111/j.1477-9552.2001.tb00923.x

HERZON, I. a kol. (2011). Importance of set-aside for breeding birds of open farmland in Finland. Agriculture, Ecosystems and Environment 143(1): 3-7. http://dx.doi.org/10.1016/j.agee.2011.05.006

KOESTER, U. (1989). Financial implications of the EC set-aside programme. Journal of Agricultural Economics 40(2): 240-248.

http://dx.doi.org/10.1111/j.1477-9552.1989.tb01103.x

MAJEWSKI, M., SULEWSKI, P. a kol. (2011). Diferences in possible reaction of EU farmers from selected European regions to CAP change. ACTA Scientiarum Polonorum, Oeconomia 10(1): 45-56.

MORRIS, A., BÁLDI, A., ROBIJNS, T. (2011). Setting aside farmland in Europe: The wider context. Agriculture, Ecosystems and Environment 143(2): 12. http://dx.doi.org/10.1016/j.agee.2011.07.013

NOVÁK, V., KADIDLOVÁ, H., BUŇKA, F. (2006). Ekonomika výživy a výživová politika II.: Vývoj zemědělské politiky EU a ČR. Zlín: UTB.

RYGNESTAD, H., FRASER, R. (1996). Land heterogeneity and the effectiveness of CAP set-aside. Journal of Agricultural Economics 47(1-4): 255-260. http://dx.doi.org/10.1111/j.1477-9552.1996.tb00689.x

Tabulka 6 Celková bilance dotací po uhrazení ušlých výnosů a pachtovného

\begin{tabular}{|l|c|c|c|c|c|}
\hline Ekonomická velikost podniku & $\begin{array}{c}\text { EVJ/ } \\
\text { podnik }\end{array}$ & $\begin{array}{c}\text { Malá } \\
\text { (III.-VI.) }\end{array}$ & $\begin{array}{c}\text { Střední } \\
\text { (VII.-VIII.) }\end{array}$ & $\begin{array}{c}\text { Velká } \\
\text { (IX.) }\end{array}$ & $\begin{array}{c}\text { Největší } \\
\text { (X.) }\end{array}$ \\
\hline Pachtovné + NUP & Kč/podnik & 30689,46 & 110348,30 & 515382,46 & 2572798,28 \\
\hline Dotace na všechny ha & Kč/podnik & 266760 & 562560 & 2006580 & 10428680 \\
\hline Krytí pachtu a NUP dotacemi & - & 8,69 & 5,10 & 3,89 & 4,05 \\
\hline
\end{tabular}

Pozn.: NUP jsou náklady ušlé prŕíležitosti. 


\section{Další zdroje}

CLÉMENT, T. a kol. (2002). Evaluation de l'impact des mesures communautaires concernant le gel des teres: Raport final. [On-line], [cit. 20. 12. 2011]. Dostupné $\mathrm{z}$ www: <http://ec.europa.eu/agriculture/ eval/reports/gel/texte.pdf>.

ČESKÝ STATISTICKÝ ÚŘAD (2010). Agrocenzus 2010. [On-line], [cit. 15. 12. 2011]. Dostupné z www: $<$ http://www.czso.cz/csu/2011edicniplan.nsf/kapitola/ 2126-11-n_2011-01>.

DEFRA (Department for environment food and rural affairs) (2011). Set-aside. DEFRA. [On-line], [cit. 07. 01. 2012]. Dostupné $\mathrm{z}$ www: <http://www.defra. gov.uk/statistics/foodfarm/enviro/observatory/setaside $>$.

EVROPSKÁ KOMISE (1992). Council regulation (EEC) No 2078/92 of 30 June 1992 on agricultural production methods compatible with the requirements of the protection of the environment and the maintenance of the countryside. Official Journal of the European Communities L 215/85. Vydáno 30. 7. 1992. [Cit. 16. 12. 2011]. Dostupné $\mathrm{z}$ www: $<$ http://eur-lex.europa.eu/LexUriServ/LexUriServ.do? uri=CELEX:31992R2078:EN:HTML>.
EVROPSKÁ KOMISE (2011). Proposal for a regulation of the European parliament and of the council on support for rural development by the European agricultural fund for rural development (EAFRD). $\operatorname{COM}(2011) 627$ final/2. [Cit. 16. 11. 2011]. Dostupné z www: <http://ec.europa.eu/agriculture/cap-post2013/legal-proposals/com627/627_en.pdf $>$.

FADN CZ 2009 (2010). Výsledky šetření za rok 2009. FADN CZ. [On-line], [cit. 07. 12.2011]. Dostupné z www: $<$ http://www.vsbox.cz/fadn/index.htm>.

FADN CZ 2011 (2011). Klasifikace ekonomické velikosti. FADN CZ. [On-line], [cit. 16. 01. 2011]. Dostupné z www: <http://www.vsbox.cz/fadn/htm/ metodiky.htm>.

AGC (2012). Normativy pro zemědělskou a potravinářskou výrobu AGroConsult. Průměrné farmářské ceny rostlinných produktů. [On-line], [cit. 07. 12. 2011]. Dostupné z www: <http://www.agronorma tivy.cz/docs/2040010_rslt.html>.

VANNINI, L. a kol. (2008). Evaluation of the Set Aside Measure 2000-2006: Final report. [On-line], [cit. 27. 12. 2011]. Dostupné z www: $<$ http://ec.europa.eu/agriculture/eval/reports/setaside/f ulltext_en.pdf $>$.

ÚZEI (Ústav zemědělské ekonomiky a informací) (2010). České zemédělství šest let po vstupu do Evropské unie. Výzkumná studie. Dostupné $\mathrm{z}$ www: $<$ http://www.uzei.cz/left-menu/publikacni-cinnost/ studie/2010/studie103.pdf>. 